\title{
The interfaces between vitamin $D$, sleep and pain
}

\author{
Daniela Leite de Oliveira, Camila Hirotsu, Sergio Tufik and Monica Levy Andersen
}

Department of Psychobiology, Universidade Federal de São Paulo, São Paulo, Brazil

Correspondence

should be addressed

to C Hirotsu

Email

milahirotsu@gmail.com

\begin{abstract}
The role of vitamin D in osteomineral metabolism is well known. Several studies have

suggested its action on different biological mechanisms, such as nociceptive sensitivity and sleep-wake cycle modulation. Sleep is an important biological process regulated by different regions of the central nervous system, mainly the hypothalamus, in combination with several neurotransmitters. Pain, which can be classified as nociceptive, neuropathic and psychological, is regulated by both the central and peripheral nervous systems. In the peripheral nervous system, the immune system participates in the inflammatory process that contributes to hyperalgesia. Sleep deprivation is an important condition related to hyperalgesia, and recently it has also been associated with vitamin D. Poor sleep efficiency and sleep disorders have been shown to have an important role in hyperalgesia, and be associated with different vitamin D values. Vitamin $D$ has been inversely correlated with painful manifestations, such as fibromyalgia and rheumatic diseases. Studies have demonstrated a possible action of vitamin D in the regulatory mechanisms of both sleep and pain. The supplementation of vitamin D associated with good sleep hygiene may have a therapeutic role, not only in sleep disorders but also in the prevention and treatment of chronic pain conditions.
\end{abstract}

Key Words

- sleep

- vitamin D

- pain

- hyperalgesia
Journal of Endocrinology (2017) 234, R23-R36

\section{Introduction}

The musculoskeletal benefits of vitamin $\mathrm{D}$ are widely known: they promote the calcification of bone matrix and increase the absorption of calcium and phosphate in the intestine. Vitamin D deficiency can cause rickets in children and osteomalacia in adults. It also contributes to bone frailty and consequent fracture in the elderly.

The endogenous synthesis of vitamin D occurs in the epidermis from the precursor 7-dehydrocholesterol (7-DHC) through ultraviolet $\mathrm{B}$ radiation (wavelengths between 290 and $315 \mathrm{~nm}$ ). Vitamin D2 (ergosterol) and vitamin D3 (cholecalciferol) can be obtained from vegetable and animal sources, such as shiitake mushrooms and salmon, respectively (Holick \& Chen 2008, IOM 2011). When both ergosterol and cholecalciferol reach the liver and kidney through circulation, two consecutive hydroxylations occur mediated by cytochrome (CYP) P450. In the kidney, 25-hydroxyvitamin D (25OHD) is converted to its metabolically active form: 1- $\alpha, 25$-dihydroxyvitamin $\mathrm{D}$, also known as calcitriol $\left(1,25(\mathrm{OH})_{2} \mathrm{D}\right)$. This active molecule $\left(1,25(\mathrm{OH})_{2} \mathrm{D}\right)$ can also be produced in different cells and tissues, such as skin, colon, placenta and prostate (Holick \& Chen 2008, EFSA 2016). Calcitriol binds to the vitamin D receptor (VDR), a transcription factor that translocates to the cell nucleus, in which it is heterodimerized with the retinoid $\mathrm{X}$ receptor (RXR). Then, the calcitriol-VDR-RXR complex couples to a specific sequence of DNA known as the vitamin $\mathrm{D}$ response element (VDRE), which is associated
() 2017 Society for Endocrinology Printed in Great Britain
Published by Bioscientifica Ltd 
with promoters of several target genes and co-activator molecules (Holick et al. 2011).

Many conditions interfere with the endogenous synthesis of vitamin D. The lower the amount of sunlight, the lower the endogenous vitamin D production. Age is also relevant, but not determinant to the reduction of 7 DHC production due to increased thickening of the skin in elderly individuals (Need et al. 1993, Holick \& Chen 2008). Additionally, skin pigmentation can modulate the synthesis of vitamin D, since the amount of melanin restricts the radiation of photons that are necessary for its endogenous production. Consequently, dark/black skin individuals need longer exposure to the sun to get optimal levels of vitamin D (Hagenau et al. 2009, Gordon et al. 2012, Correia et al. 2014).

Vitamin D status is based on the serum levels of 25OHD, the metabolite found in the human body in higher concentration. Currently, there is a debate about the optimal reference value of vitamin $\mathrm{D}$, which is primarily based on bone health parameters. Different scientific committees' panels indicate that 25OHD serum levels lower than $20 \mathrm{ng} / \mathrm{mL}$ are appropriate for good health in the general population (IOM 2011, EFSA 2016, SACN 2016). On the other hand, the Endocrine Practice Guideline suggests a screening in groups at risk for vitamin D deficiency (Holick et al. 2011). In this guideline, individuals with 25OHD serum levels of $20 \mathrm{ng} / \mathrm{mL}$ are considered as deficient for vitamin $\mathrm{D}$, while serum levels above $30 \mathrm{ng} / \mathrm{mL}$ are considered sufficient to provide health benefits (Holick et al. 2011). Manson and colleagues (Manson et al. 2016) have addressed this issue by emphasizing that the suggested values for $25 \mathrm{OHD}$ sufficiency of $>30 \mathrm{ng} / \mathrm{mL}$ are due to a misinterpretation and misunderstanding of the reference value indicated by the IOM. For clinical practice, it is important to establish a cut-off point. However, this requires more standardized studies, since most experimental designs available in the literature were not well controlled for confounders and based solely on bone health.

25OHD serum levels have been associated with several comorbidities such as infectious, autoimmune and neurological diseases, as well as neuromuscular disorders, which can lead to increased pain sensitivity (Dhesi et al. 2002, Orme et al. 2013, Lachmann et al. 2015). Regarding the mechanisms of pain sensitization, vitamin D seems to stimulate anti-inflammatory processes in some cases and thus to relieve the painful sensation of many diseases (Adorini \& Penna 2008, Osunkwo et al. 2011, Le Goaziou et al. 2014). It is important to mention that the anti-inflammatory actions on pain conditions are not specific for vitamin D. Recently, researchers have suggested the participation of vitamin $\mathrm{D}$ in regulatory mechanisms of sleep-wake cycle, based on the evidence suggesting that the reduction of this vitamin is also associated with sleep disorders (McCarty et al. 2012, Mete et al. 2013, Çakır et al. 2015, Kerley et al. 2016).

This proposed ability of vitamin $\mathrm{D}$ to act on both the sleep-wake cycle and the nociceptive process may be due to the fact that they share some neurotransmitters in similar pathways. In this review, we aim to explore the current knowledge about the association between sleep and pain and to consider the role that vitamin D may play in this relationship. Finally, we will highlight new perspectives about the potential applicability vitamin D may have in sleep disorders and chronic painful conditions.

\section{Vitamin D and sleep}

\section{Sleep regulation}

Sleep is a complex physiological state, and although often thought as an inactivity period, it comprises a period of intense metabolic activity. Its function is still not fully understood, although it is known that this biological phenomenon participates in several processes, e.g., learning, consolidation of memory, inflammation, and metabolic disorders, being essential to good mental and physical health (Walker \& Stickgold 2004, Van Cauter et al. 2008, Hirotsu et al. 2012, Ruiz et al. 2012, Garcia et al. 2013, Davis et al. 2017).

Sleep is classified into the rapid eye movement (REM) stage, also known as paradoxical sleep, and the non-REM (NREM) or slow-wave sleep stage. NREM sleep is characterized by cortical synchronization, muscular hypotonia and endocrine regulation. REM sleep presents cortical desynchronization, muscle atonia, rapid eye movements and dream activity (Jouvet 1967, Carskadon $\&$ Dement 2017).

The sleep-wake cycle is modulated by different regions of the central nervous system (CNS). Its main regulation occurs in the ventrolateral preoptic nucleus (VLPO) of the hypothalamus through interaction with circadian and homeostatic factors. A set of neurons from the suprachiasmatic nucleus is activated by circadian influences such as absence and/or presence of light, while hypnogenic homeostatic factors such as adenosine accumulation in the forebrain are induced by prolonged wakefulness or decreased by sleep (Saper et al. 2005). Another important factor in the regulation of sleep is the presence of melatonin, an endogenous hormone

Published by Bioscientifica Ltd 
produced by the pineal gland and responsible for the regulation of circadian rhythms. The absence of light stimulates melatonin production, leading to sleep facilitation. During the daytime, the light stimulus is processed by the retina and sent to the suprachiasmatic nucleus, inhibiting melatonin synthesis and promoting wakefulness (McArthur et al. 1991, Cajochen et al. 2003).

During wakefulness, due to its higher behavioral complexity, numerous neural systems are activated in the brainstem reticular formation, which is a network of cells and fibers that project throughout the cerebral cortex, producing cortical activity and controlling the waking state (Jones 2011). Acetylcholine, norepinephrine, histamine and hypocretin neurotransmitters participate in the cortical activation process, while dopamine and serotonin participate in both cortical and behavioral activation. Conversely, $\gamma$-aminobutyric acid (GABA), an inhibitory neurotransmitter, is associated with sleep. From the VLPO, neuronal GABAergic projections inhibit the release of hypocretin, acetylcholine, norepinephrine, serotonin and dopamine, resulting in brain synchronization. During REM sleep, however, there is continued inhibition of these neurotransmitters, except for acetylcholine, which provides cortical activity during REM sleep (España \& Scammell 2011).

The advance of technology and increased urbanization over the 20th and 21st centuries caused the suppression of melatonin synthesis by artificial light produced at night. This has led to extended periods of wakefulness and sleep curtailment. Sleep deprivation induced by exposure to artificial light causes several impairments in the regulation of biological rhythms, cognition and brain development, leading to long-term negative impacts on quality of life (Thomas et al. 2000, Durmer \& Dinges 2005, Tufik et al. 2009).

The most common sleep disorders in the general population are obstructive sleep apnea (OSA) and insomnia, followed by others of lower prevalence such as sleep-related movement disorders, parasomnias and central hypersomnolence disorders. OSA is a sleep disordered breathing condition that affects one-third of the general population and is characterized by complete or partial obstruction of the upper airways resulting in a higher apnea-hypopnea index (AHI $>15$ ), snoring, morning headaches and dry mouth (Tufik et al. 2010). Risk factors for OSA include obesity and being male and older. The cardiovascular system is also impaired in OSA due to intermittent hypoxia, sleep fragmentation and reduction of intrathoracic pressure. This condition may lead to vascular injury contributing to the increase of systemic blood pressure (Drager et al. 2013, Franklin \& Lindberg 2015).

Insomnia is characterized by a difficulty in initiating and/or maintaining sleep or early awakening with a frequency of more than 3 times a week over a period of 3 months (ICSD-3, 2014), and affects around 15-45\% of the general population. Individuals with insomnia frequently have a non-restorative sleep and may present early awakenings. Among the predisposing and risk factors are female gender, anxiety and depression (Castro et al. 2013).

\section{Vitamin D and sleep}

The recent interest in the role of vitamin D as a sleep modulator is based on studies in both animal models and humans, indicating the neuronal expression of CYP27B1 and VDR in different brain areas, especially in regions that also regulate the sleep-wake cycle, such as the hypothalamus (Stumpf \& O’Brien 1987, PérezFernandez et al. 1997, Prüfer et al. 1999, Eyles et al. 2005, 2014).

The association between sleep disorders and 25OHD values has increased in the last decade (Andersen \& Tufik 2012, Bozkurt et al. 2012, Kheirandish-Gozal et al. 2014, McCarty et al. 2014, de Oliveira et al. 2015, Evatt 2015). The possible mechanisms involved in this association are not clear, suggesting that additional studies are required to understand the potential role of vitamin D in physiological sleep mechanisms. Table 1 summarizes the current findings from the clinical literature. One of the first studies showed a significant association between excessive daytime sleepiness and serum values of $25 \mathrm{OHD}<20 \mathrm{ng} / \mathrm{mL}$ only in black individuals (McCarty et al. 2012). Valtueña et al. (2013) found that lower levels of 25OHD concentrations were associated with shorter sleep duration $(<8 \mathrm{~h})$ in female teenagers. In this study, sleep duration was assessed by self-administered questionnaires, which only provide subjective information about the sleep pattern of subjects. Recently, other studies have evaluated the relationship between serum 25OHD levels and sleep using objective parameters. Low $25 \mathrm{OHD}$ serum levels $(<30 \mathrm{ng} / \mathrm{mL})$ were associated with shorter sleep duration $(<5 \mathrm{~h})$ measured by actigraphy among men (Massa et al. 2015). Similarly, Bertisch et al. (2015) reported that shorter sleep duration $(373.3 \pm 80.7 \mathrm{~min})$ measured by polysomnography was significantly associated with 25OHD serum levels lower than $20 \mathrm{ng} / \mathrm{mL}$, while a lower proportion of REM sleep was weakly correlated with $25 \mathrm{OHD}$ values between 20 and $29 \mathrm{ng} / \mathrm{mL}$. In addition, a study using actigraphy in

Published by Bioscientifica Ltd. 


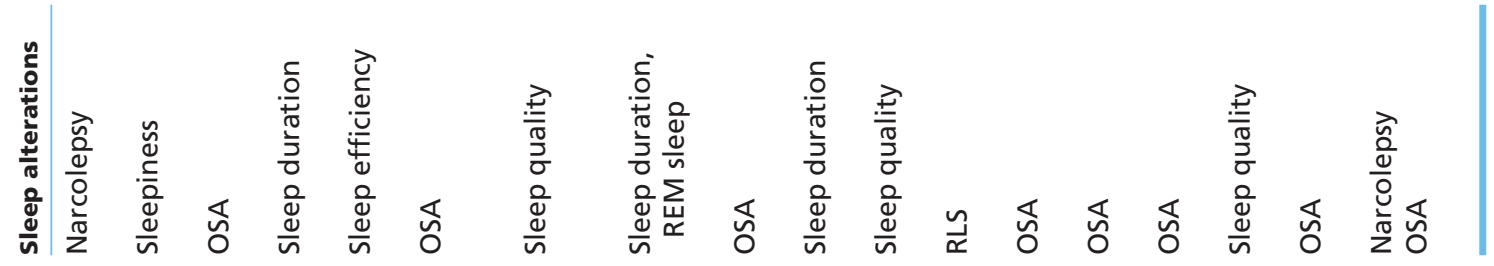

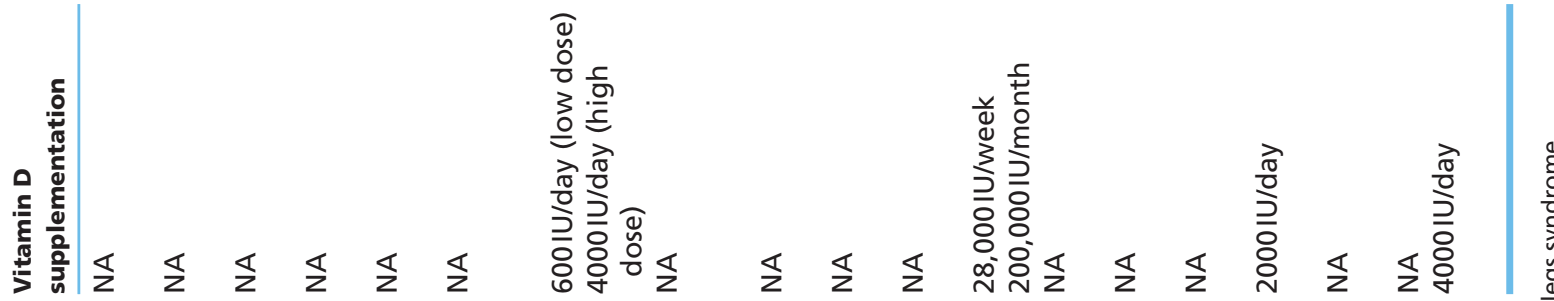

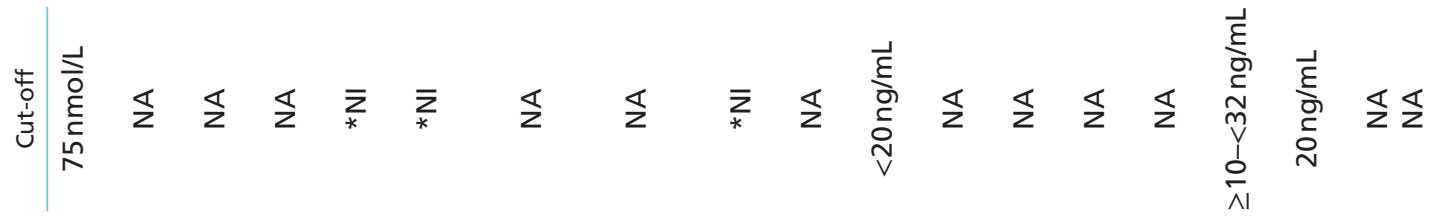

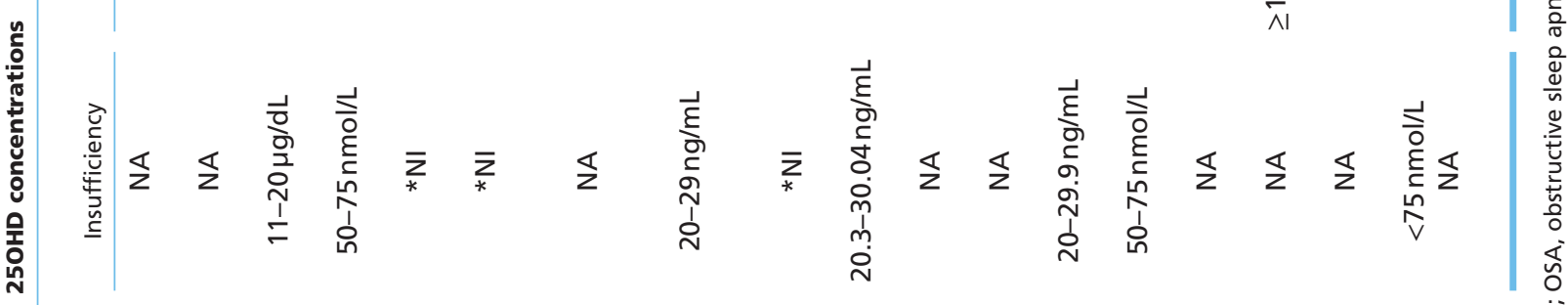

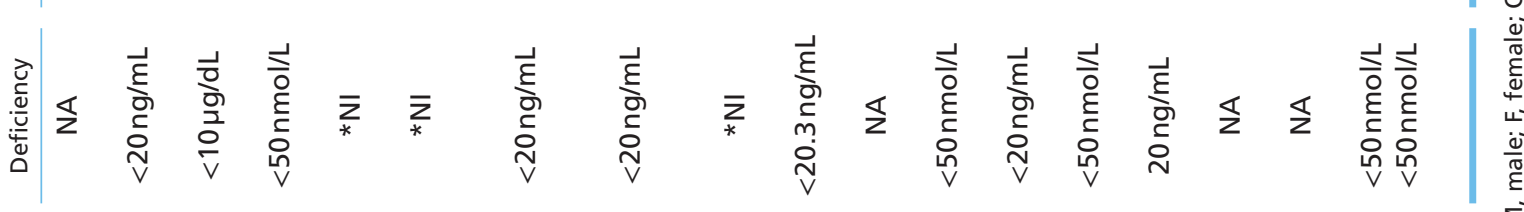

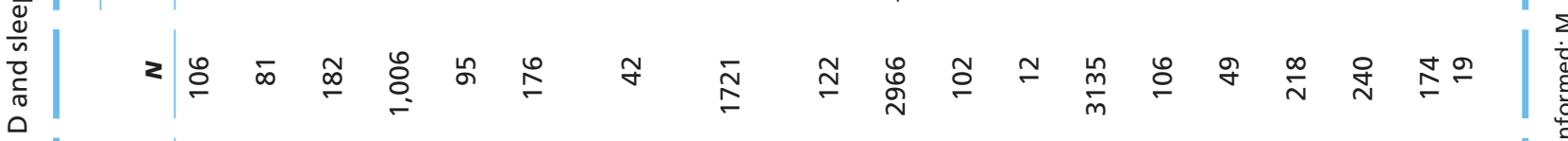

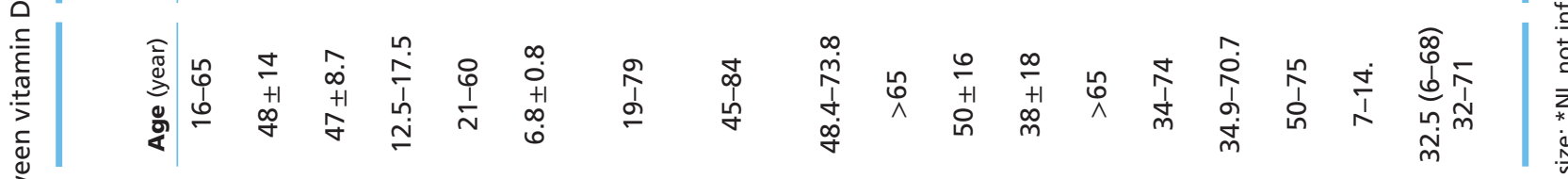

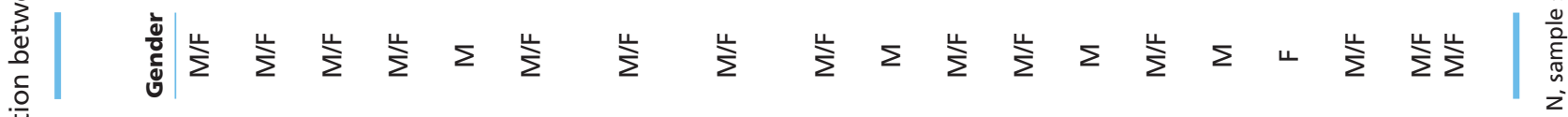

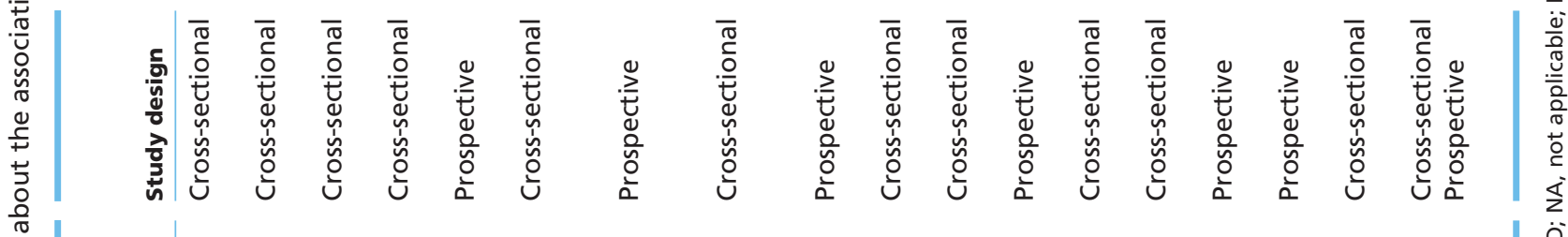

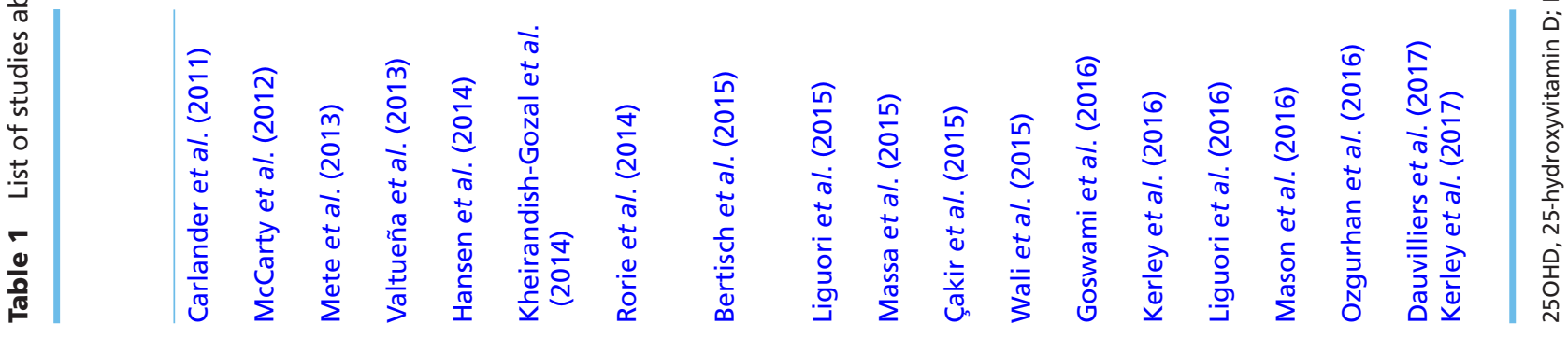


male forensic patients demonstrated that sleep latency decreased in the group who was submitted to a fishenriched diet compared to the control group. Moreover, 25OHD serum levels increased with fish consumption, and a positive correlation between vitamin $\mathrm{D}$ and sleep efficiency was found (Hansen et al. 2014). It is important to highlight the heterogeneous characteristics of the sample in this study, such as age, gender and the presence of comorbidities, which hamper the establishment of a clear relationship between vitamin D and sleep maintenance.

Other studies have demonstrated that in patients with OSA, the higher the body mass index (BMI) and AHI, the lower the 25OHD levels (Mete et al. 2013, Kerley et al. 2016). Additionally, Goswami and coworkers (2016) found that BMI and neck circumference could be a confounding factor in the association observed between $25 \mathrm{OHD}$ serum levels $<20 \mathrm{ng} / \mathrm{mL}$ and some risk factors for OSA. A further study revealed that the use of continuous positive airway pressure (CPAP), the gold standard for OSA treatment, promoted increased levels of 25OHD (from $19.21 \pm 9.45 \mathrm{ng} / \mathrm{mL}$ to $21.03 \pm 9.50 \mathrm{ng} / \mathrm{mL}$ ) (Table 1) in men with OSA after 7 days of CPAP use (Liguori et al. 2015). The CPAP therapy was also effective in increasing $25 \mathrm{OHD}$ serum concentrations from $16.05 \pm 7.74 \mathrm{ng} / \mathrm{mL}$ to $25.73 \pm 12.91 \mathrm{ng} / \mathrm{mL}$ after 1 year of treatment in both obese and non-obese OSA patients (Liguori et al. 2016). The increase in serum 25OHD levels and decrease in both sleepiness and AHI were mainly observed in the obese patients compared to non-obese OSA men treated with CPAP. A pilot study assessing Caucasian OSA individuals submitted to cholecalciferol supplementation (4000 IU/ day) during 15 weeks (Kerley et al. 2017) showed an increase in 25OHD serum levels in the supplemented group vs placebo $(100.8 \pm 39.9 \mathrm{nmol} / \mathrm{L} \times 43.0 \pm 21.4 \mathrm{nmol} / \mathrm{L}$, respectively), and a decrease in metabolic parameters such as low-density lipoprotein (LDL) and lipoproteinassociated phospholipase A2 (Lp-PLA2). Some subjects from both groups used CPAP, but the data were not controlled, hampering the interpretation about the benefits of the supplementation since there is current evidence that CPAP use can increase 25OHD levels (Liguori et al. 2015).

In pediatric patients, the clinical condition is similar. Obese children present lower serum levels of 25OHD $(83.6 \pm 19.2 \mathrm{ng} / \mathrm{mL})$ compared to non-obese children $(97.1 \pm 20.9 \mathrm{ng} / \mathrm{mL}) ;$ and obese children with OSA have lower 25OHD levels than obese children without OSA (Kheirandish-Gozal 2014). Assessing the risk of developing OSA using the Pittsburg Sleep Quality Index (PSQI) questionnaire, Ozgurhan and coworkers (2016) found that children of both sexes with serum 25OHD levels ranging $13.10 \pm 4.02 \mathrm{ng} / \mathrm{mL}$ had a higher risk of developing OSA than the control group $(27.12 \pm 5.63 \mathrm{ng} /$ $\mathrm{mL}$ ). The group at high risk of developing OSA presented a higher BMI compared to those at low risk.

Restless legs syndrome (RLS) is a sleep-related movement disorder that has also been linked to lower levels of vitamin D. An urge to move the legs characterizes this syndrome, mainly during the end of the day, which ameliorates with movement and whose physiopathology is associated with a possible dysfunction in dopaminergic neurotransmission. RLS affects sleep quality by increasing both sleep latency and daytime sleepiness. Using the PSQI questionnaire, RLS was found to be more frequent in individuals with serum 25OHD levels $<20 \mathrm{ng} / \mathrm{mL}$ compared to controls (serum 25OHD $>20 \mathrm{ng} / \mathrm{mL}$ ) (Çakır et al. 2015) (Table 1). Vitamin D supplementation (28,000IU/week; 200,000/month) showed a decrease in RLS severity in patients compared to their baseline (serum 25OHD at baseline: $21.7 \mathrm{nmol} / \mathrm{L}$ (13.45-57.4); serum 25OHD after supplementation: $61.8 \mathrm{nmol} / \mathrm{L}$ (42.58-95.9)) (Table 1) (Wali et al. 2015). $1,25(\mathrm{OH})_{2} \mathrm{D}$ acts on dopaminergic neurons and its in vitro action increases the expression of $\mathrm{N}$-cadherin, a molecule that participates in the neurogenesis of dopaminergic neurons and that possibly regulates the expression of tyrosine hydroxylase enzyme, a rate-limiting molecule in the dopamine synthesis pathway (Cui et al. 2013, 2015, Jiang et al. 2014a,b).

In individuals diagnosed with narcolepsy with cataplexy, a central hypersomnolence disorder, the serum 25OHD levels were lower compared to individuals without the disease $(59.45 \mathrm{nmol} / \mathrm{L} \times 74.73 \mathrm{nmol} / \mathrm{L}$, respectively) (Table 1) (Carlander et al. 2011). Recently, Dauvilliers and coworkers (2017) did not find any association between narcolepsy individuals (77.46 (21.10-209.9) nmol/L) and serum 25OHD levels $<20 \mathrm{ng} / \mathrm{mL}$ compared to the control group $(77.21(3.73-437.25) \mathrm{nmol} / \mathrm{L})$. Narcolepsy is a sleep disorder characterized by excessive sleepiness that can be or not associated with cataplexy (reduced muscle tonus without loss of consciousness) and hallucinations. The mechanism of narcolepsy is attributed to the decrease in the concentration of hypocretin, a neuropeptide responsible for wakefulness in the CNS.

In a placebo-controlled randomized clinical trial with postmenopausal women participating in a weight loss program (Table 1), Mason and coworkers (2016) reported that individuals undergoing cholecalciferol supplementation (2000IU/day for 12 months) had impaired subjective sleep quality as assessed by the PSQI

Published by Bioscientifica Ltd. 
questionnaire. However, another randomized study reported cholecalciferol supplementation (4000IU/day for 12 weeks) benefitted sleep (Table 1) in chronic urticaria patients. The authors found a trend of improvement in sleep quality in the high-vitamin D supplemented group compared to the low-vitamin D supplemented one (600 IU/day) (Rorie et al. 2014). The different designs of both studies make it difficult to conclude whether vitamin D supplementation has beneficial effects on sleep quality.

\section{Vitamin D and pain}

\section{Pain regulation}

According to the International Association for the Study of Pain (IASP), pain is an unpleasant sensory and emotional experience associated with actual or potential tissue damage or described in terms of such damage (IASP 1994). It can be classified into nociceptive, originating in the mechanical, thermal or chemical nociceptors (sensory neurons) of the physical area in which the injury occurs; neuropathic, caused by injury or disease of the nervous system; or psychological, from an emotional origin. Acute pain comes from inflammation or tissue damage and is related to tissue repair and the healing process. Chronic pain persists for the period of injury, causing damage to the individual's quality of life (Schaible \& Richter 2004).

The most important nerve centers responsible for the transmission of nociceptive information are the thalamus, midbrain, limbic system and reticular formation. The nociception process consists of 3 stages: stimulus transduction by first-order neurons of the spinal cord, where neurotransmitters such as glutamate, substance $\mathrm{P}$ and calcitonin are released and activate second-order neurons. These, in turn, transmit information to the thalamus, where the pain sensitivity occurs. Third-order neurons connect the thalamus to the cortex, activating it and resulting in pain perception (Schaible \& Richter 2004, Klaumann et al. 2008).

Several neurotransmitters play a role in the pain sensitization process. Norepinephrine, dopamine and serotonin modulate the descending pain pathway by inhibition or excitation of their target receptors. Nitric oxide acts on nociceptive sensitivity (Meller \& Gebhart 1993, Millan 2002). Prostaglandin E2 ( $\left.\mathrm{PGE}_{2}\right)$ contributes to inflammatory pain (Kawabata 2011).

Another important component of pain mechanism is the immune system. Because of injury, inflammation of the damaged tissue may cause hyperalgesia. Activation of macrophages in the damaged peripheral tissues results in the release of proinflammatory cytokines, such as tumor necrosis factor alpha (TNF- $\alpha$ ), interleukin-1 beta (IL-1 $\beta$ ), neuronal growth factor (NGF), nitric oxide and $\mathrm{PGE}_{2}$. Neutrophils are also recruited in this process by inflammation-producing substances such as cytokines and chemokines. The accumulation of these cells in inflammatory processes leads to opioid expression, with antinociceptive effects (Marchand et al. 2005, Ren \& Dubner 2010, Shipton \& Shipton 2015).

In the last decades, studies have suggested the action of the active form of vitamin $\mathrm{D}\left(1,25 \mathrm{OH}_{2} \mathrm{D}\right)$ in several cell types of the immune system. It acts in Th2 cells by increasing the synthesis of interleukin-4 (IL-4) and transforming growth factor- $\beta$ (TGF- $\beta$ ) (Deluca \& Cantorna 2001). It is known that TGF- $\beta$ decreases the expression of proinflammatory cytokines, such as interferon- $\gamma$ (IFN- $\gamma$ ), IL- 1 and TNF- $\alpha$. Both TGF- $\beta$ and IL- 4 are found in microglial cells (Garcion et al. 2002). Vitamin D inhibits the action of $\mathrm{PGE}_{2}$ by inhibiting its precursor, cyclooxygenase-2 (COX2) (Moreno et al. 2006). Finally, studies have shown that $1,25(\mathrm{OH})_{2} \mathrm{D}$ precludes the synthesis of inducible nitric oxide synthase (iNOS), an enzyme that produces large amounts of nitric oxide when stimulated (Garcion et al. 2002). These regulatory pathways are involved in pain sensitization and $1,25(\mathrm{OH})_{2} \mathrm{D}$ appears to regulate important molecules involved in this process, suggesting it has a potential neuro-immunomodulatory action.

\section{Vitamin D and pain}

Different anatomical regions may be the targets of musculoskeletal pain such as the lower limbs (legs and knees) and back. This chronic pain condition causes socioeconomic and psychological harms. Moreover, the cause of these disorders is often associated with several factors such as age, gender, diet and psychological status (McBeth \& Jones 2007). Researchers have shown that women with $25 \mathrm{OHD}$ serum levels $<20 \mathrm{ng} / \mathrm{mL}$ have a higher chance of developing pain (Table 2) (Hicks et al. 2008, Heidari et al. 2010). Several studies have indicated that vitamin D supplementation (Table 2) is effective in reducing complaints in specific or nonspecific musculoskeletal pain disorders (Schreuder et al. 2012, Gendelman et al. 2015, Yilmaz et al. 2016, Ghai et al. 2017). In a recent meta-analysis (Table 2), Wu and colleagues (Wu et al. 2016) reported, in a subgroup analysis of vitamin D group vs placebo, that vitamin D supplementation for an average time duration of 


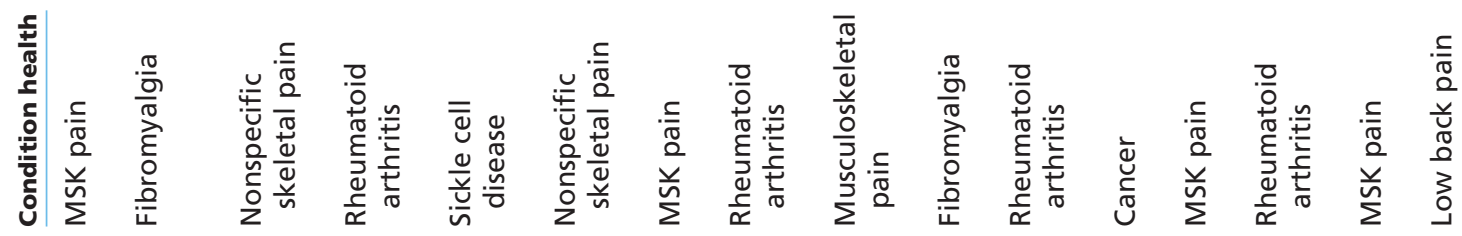

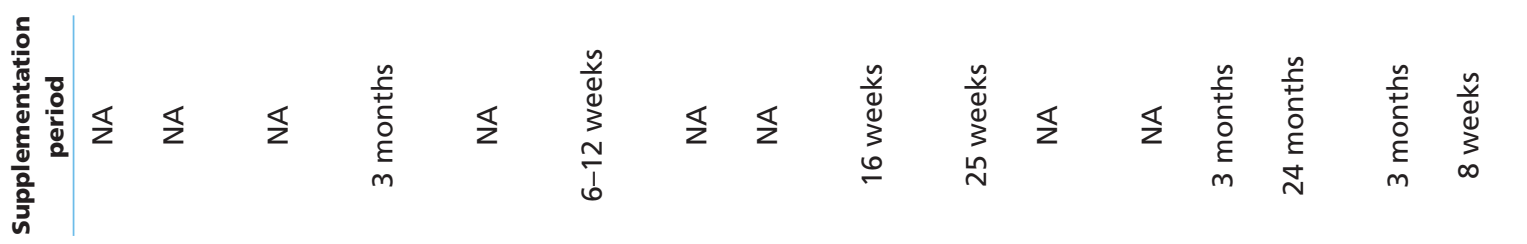

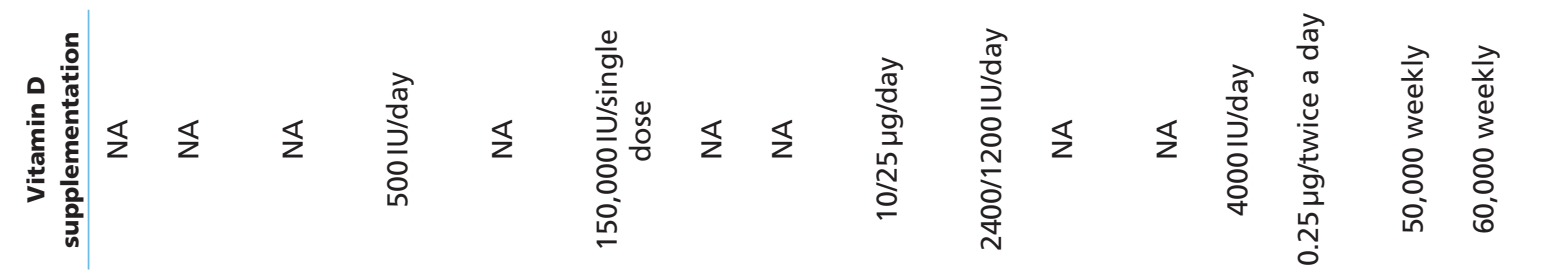

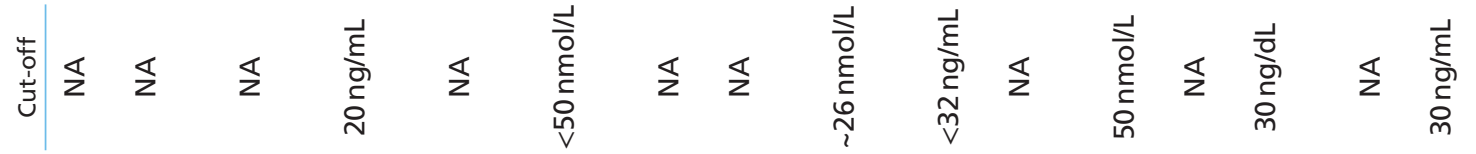

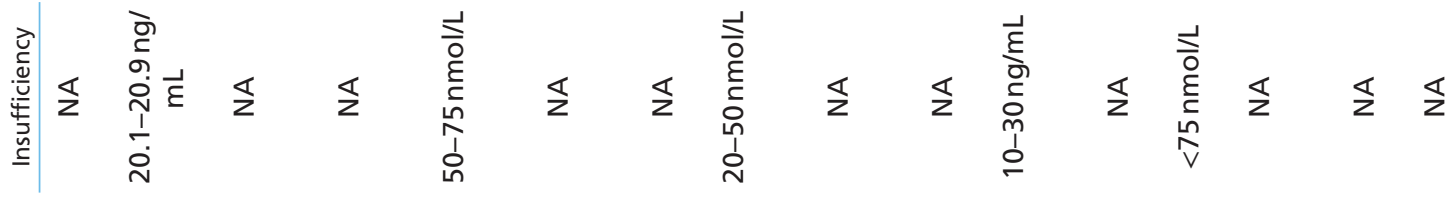

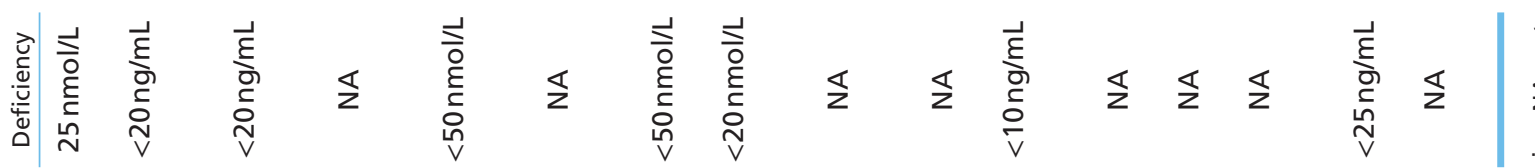

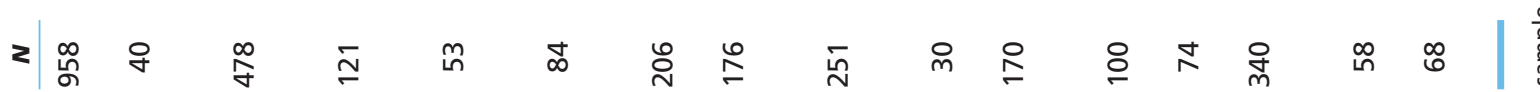

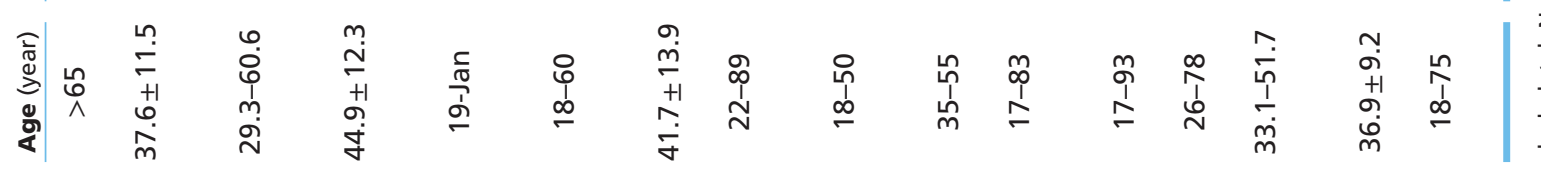
离

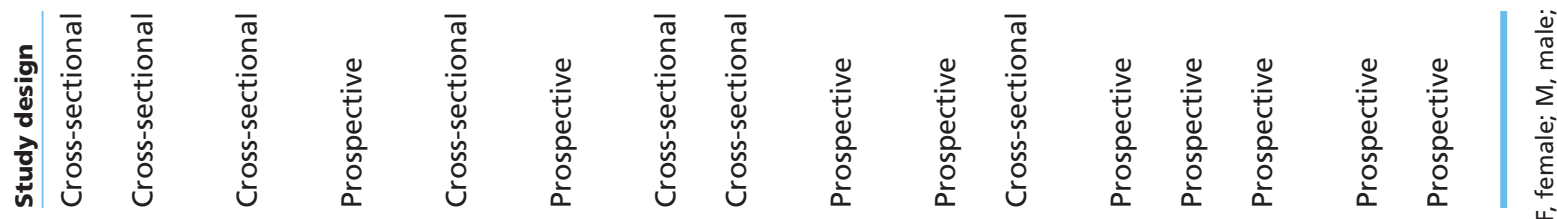


3 months reduced pain in conditions such as myalgia, arthritis and chronic musculoskeletal pain. This result was observed in hospitalized patients with pain-related medical conditions. Although some studies have shown a negative association between musculoskeletal pain and serum 25OHD, little is known about the mechanisms involved in this relationship (Table 2) (Al-Jarallah et al. 2013, Knutsen et al. 2014).

In fibromyalgia, a diffuse chronic pain syndrome, there are reports of an inverse relationship between serum $25 \mathrm{OHD}$ and pain. When evaluating the 25OHD concentrations among women with fibromyalgia, a study showed lower levels in younger compared to older women. There was no information about a control group (Table 2) (Bhatty et al. 2010). This study was performed in Pakistan, a region where women's typical clothing is the burqa, which hinders endogenous vitamin D synthesis. Wepner and coworkers (2014) supplemented individuals with fibromyalgia using 2400 or $1200 \mathrm{IU} /$ day to reach serum $25 \mathrm{OHD}$ levels of $32-48 \mathrm{ng} / \mathrm{mL}$ (Table 2). According to the visual analog scale (VAS), the pain score of the treated group reduced over the weeks of supplementation. Another point to be considered is that vitamin D deficiency causes osteomalacia, a painful bone disease, which can often be confused or misdiagnosed as fibromyalgia (Holick 2003, Plotnikoff \& Quigley 2003).

In rheumatic diseases, such as rheumatoid arthritis or osteoarthritis, the results for the inverse correlation between vitamin $\mathrm{D}$ and pain complaints are in the same direction (Table 2) (Gopinath \& Danda 2011, Higgins et al. 2013, Abourazzak et al. 2015, Yang et al. 2015). These disorders are also characterized as autoimmune diseases. For this reason, another hypothesis suggests that pain relief in these patients could be modulated by the action of $1,25(\mathrm{OH})_{2} \mathrm{D}$ in the immune system and not only in the pain-regulating mechanism. Vitamin $\mathrm{D}$ also presents a potential immunomodulatory response in autoimmune diseases. A prospective study, including men and women with an age range of 18-71 years, reported that an elevation of $10 \mathrm{nmol} / \mathrm{L}$ on vitamin D status was associated with lower incidence of diseases such as multiple sclerosis, type 1 diabetes, Crohn's disease and thyrotoxicosis (Skaaby et al. 2015). It is known that $1,25(\mathrm{OH})_{2} \mathrm{D}$ modulates some actions of the immune system. It suppresses the proinflammatory response (Th1) and stimulates the anti-inflammatory response (Th2), which leads to an immunological tolerance and consequently attenuates the clinical condition of the autoimmune disease (Kamen $\&$ Tangpricha 2010).
Other comorbidities can also cause chronic pain. In young individuals with sickle cell disease, both pain and increased bone frailty were associated with serum 25OHD levels $<20 \mathrm{ng} / \mathrm{mL}$ (Table 2) (Osunkwo et al. 2011). In individuals under treatment for cancer, serum 25OHD levels were related to the use of opioids. Low levels of $25 \mathrm{OHD}(<20 \mathrm{ng} / \mathrm{mL})$ led to higher doses of opioids for pain relief, while high serum $25 \mathrm{OHD}$ levels were a predictor of longevity (Table 2) (Bergman et al. 2015).

\section{Sleep and pain}

Changes in sleep pattern are common in the population and contribute to several impairments of the physiological system, leading to increased cardiovascular risk, reduction in immune defense, cognitive impairment and increased pain sensitivity (Meier-Ewert et al. 2004, Durmer \& Dinges 2005, Nascimento et al. 2007, Zager et al. 2007, Roizenblatt et al. 2015).

The use of animal models has provided a better understanding of the effects of sleep on pain and viceversa, mimicking the physiological and behavioral manifestations observed in humans (Andersen et al. 2006). In rats with chronic constrictive injury, lower sleep efficiency, a higher number of awakenings and longer sleep latency were observed, as well as a reduction in NREM sleep (Andersen \& Tufik 2003). These results showed that pain was associated with intrinsic changes in sleep architecture. These findings have been confirmed in humans. A survey evaluating the impact of dysmenorrhea on sleep profile showed that women who had menstrual cramps presented longer REM sleep latency (Araujo et al. 2011). Changes in sleep pattern have also been found in women with fibromyalgia, who have shown intrusion of high-frequency brainwaves during NREM sleep in association with hypersensitivity and increased subjective pain (Smith et al. 2009). The reduction in both sleep efficiency and slow wave sleep are associated with fatigue in this disease. The treatment of pain conditions may be helpful for sleep quality. A randomized placebo-controlled study evaluated the efficacy of pregabalin use, a drug for fibromyalgia treatment, on the management of pain (Arnold et al. 2015). Women were more prevalent in this cohort (93\%), and the participants were taking antidepressant medication early in the study, such as selective serotonin reuptake inhibitor (SSRI) or serotonin/norepinephrine reuptake inhibitor (SNRI). The results showed that the treated group had a decrease in mean pain score at

Published by Bioscientifica Ltd. 
the end of the study, and sleep quality was improved compared to placebo.

Sleep changes can also trigger painful conditions. Acute reduction of sleep time in healthy pain-free individuals caused hyperalgesia in the following morning (Roehrs et al. 2006). This study also found that REM sleep deprivation decreased the finger withdrawal latency for pain sensation compared to individuals that had $8 \mathrm{~h}$ of normal sleep. A meta-analysis corroborates these findings, revealing that sleep deprivation impairs pain perception (Schrimpf et al. 2015). Positive insomnia symptoms, at baseline assessment, were predictive of developing a painful condition (Finan et al. 2013). Insomnia frequency and severity among men and women ranging from 30 to 87 years old are also related to pain sensitivity. Sivertsen and coworkers (2015) demonstrated a higher hazard ratio $(52 \%)$ to painful conditions among individuals from both sexes who reported insomnia more than once a week. Just as it has been shown that decreasing pain improves sleep, it has also been demonstrated that a restorative sleep is a predictor of pain resolution. Davies and coworkers (2008), assessing chronic widespread pain and sleep quality through questionnaires, reported that restorative sleep was associated with chronic pain resolution among younger participants compared to individuals with chronic persistent pain. After controlling for confounders, restorative sleep remained as the sleep component associated with pain resolution.

In general, pain can cause changes in sleep pattern resulting in a non-restorative, superficial and fragmented sleep, with longer onset latency. Some painful conditions are frequently studied regarding sleep disorders including fibromyalgia, rheumatoid arthritis, low back pain, systemic lupus erythematosus, as well as those associated with

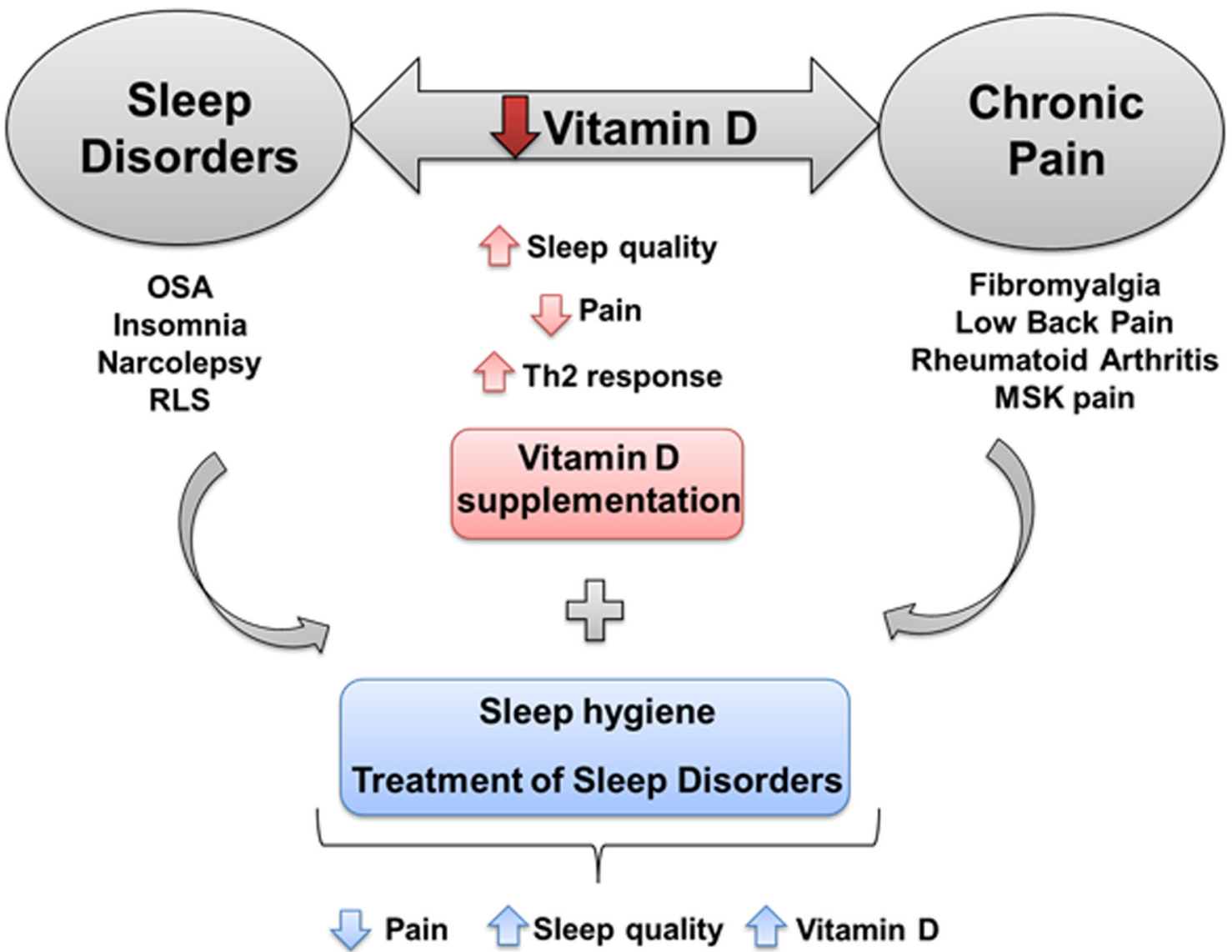

Figure 1

Hypothesis about the beneficial role of vitamin D on sleep and pain. Chronic pain and sleep disorders share a bidirectional relationship, in which vitamin $D$ deficiency may play an important role. The vitamin $D$ supplementation in sleep conditions associated with vitamin $D$ deficiency or insufficiency may bring benefits to the well-being and quality of life of patients. $1,25(\mathrm{OH})_{2} \mathrm{D}$ stimulates the anti-inflammatory response mediated by type $2 \mathrm{~T}$ helper cells (Th2), decreasing pain sensitivity, and thereby, improving sleep quality. Sleep hygiene, in addition to the treatment of sleep disorders, may also lead to a decrease in pain sensitivity by increasing serum levels of 25-hydroxyvitamin D and favoring sleep pattern. MSK, musculoskeletal; OSA, obstructive sleep apnea; RLS, restless legs syndrome. 
comorbidities, such as dysmenorrhea, tumor, and cardiac or neurological diseases. A prospective study showed that participants ( $55 \%$ women) with sleep complaints had an increased probability (from $14 \%$ to $38 \%$ ) of developing chronic pain 3 years later (Bonvanie et al. 2016). Although many researchers support the hypothesis of a bidirectional relationship between sleep and pain, others suggest a unidirectional association, in which alterations in the sleep pattern predict the occurrence of pain (Finan et al. 2013). Both longitudinal and cross-sectional studies have shown that sleep problems are a preponderant factor for the development of pain.

Sleep and pain share neurotransmitters in their physiological processes. Compared to wakefulness, during normal sleep the release of serotonin is decreased; under conditions of sleep deprivation, its release is further reduced (Blanco-Centurion \& Salin-Pascual 2001, Roehrs et al. 2006), which contributes to nociceptive pain stimulation. Thus, the use of drugs, such as SSRI, SNRI or tricyclic antidepressants, can improve both sleep and pain problems as its mechanism of action inhibits serotonin reuptake, resulting in elevated extracellular levels of this neurotransmitter.

Pain is also present in individuals with OSA. In a crosssectional study with individuals of both sexes, morning headaches were more frequent in OSA patients compared to those without OSA (Kristiansen et al. 2011). In a prospective study, Johnson and coworkers (2012) reported that headaches in individuals with OSA improved after CPAP treatment. Unfortunately, the duration of CPAP treatment in this study was not clear.

\section{Future perspectives: vitamin D, sleep and pain}

Based on the literature, vitamin D status seems to have an important role in the bidirectional relationship observed between sleep and pain. A study evaluating the effects of cholecalciferol supplementation (1200IU/ day to individuals with serum 25OHD between 20 and $29 \mathrm{ng} / \mathrm{mL}$ and $50,000 \mathrm{IU} /$ weekly to those with serum $25 \mathrm{OHD}<20 \mathrm{ng} / \mathrm{mL}$ ) in veterans with multiple areas of chronic pain found a decrease in self-reported pain in both supplemented groups, as well as an improvement in sleep pattern, with decreased sleep latency and increased sleep duration (Huang et al. 2013). In another study, patients with nonspecific chronic pain selected from a sleep clinic showed serum $25 \mathrm{OHD}$ levels $<20 \mathrm{ng} / \mathrm{mL}$
(McCarty et al. 2013). The risk factors for the decrease of vitamin D status in this study were ethnicity, obesity and age. In patients with hyperparathyroidism supplemented with vitamin $\mathrm{D}$ after parathyroidectomy, a decrease in RLS symptoms (from $56.2 \%$ to $21.0 \%$ ) and pain relief were observed (Santos et al. 2016). Although it resulted in an increase in serum 25OHD levels, there was no significant correlation between 25OHD levels and RLS severity.

The data presented in Tables 1 and 2 highlight the most relevant studies linking the relationship between vitamin $\mathrm{D}$, pain and sleep. The different study designs and cutoffs of vitamin $\mathrm{D}$, as well as the distinct vitamin D supplementation protocols, make the establishment of adequate doses of vitamin D still difficult. Nevertheless, this review brings important information regarding the benefits of vitamin D for pain-related conditions and sleep disturbances. Thus, we can hypothesize that suitable vitamin D supplementation combined with sleep hygiene may optimize the therapeutic management of pain-related diseases such as fibromyalgia (Fig. 1). As $1,25(\mathrm{OH})_{2} \mathrm{D}$ stimulates an anti-inflammatory immune response, this mechanism may induce an antinociceptive action. Sleep hygiene consists of several interventions to improve sleep, i.e. changes in the habits that precede sleep, such as avoiding the consumption of alcoholic and caffeinated drinks; reducing lighting in the bedroom and use of electronic appliances; and maintaining regular sleep schedules. For individuals with insomnia, pharmacological treatment combined with other techniques such as cognitive behavioral therapy is helpful in promoting sleep quality and reducing pain sensitivity (Finan et al. 2014). Finally, OSA treatment with CPAP can improve both pain perception and 25OHD levels. These data indicate the importance of considering the sleeppain-vitamin D inter-relationship during anamnesis by clinicians, sleep physicians and neurologists, so that the best intervention is chosen to provide the patient with a better quality of life.

\section{Declaration of interest}

The authors declare that there is no conflict of interest that could be perceived as prejudicing the impartiality of this review.

\section{Funding}

Our studies have been supported by grants from the Associação Fundo de Incentivo à Pesquisa (AFIP) and the São Paulo Research Foundation (FAPESP, \#2014/15259-2 to C H, \#2016/02205-7 to D L O). (c) 2017 Society for Endocrinology Printed in Great Britain
Published by Bioscientifica Ltd 


\section{Author contribution statement}

All the authors equally contributed to the final version of the manuscript.

\section{References}

Abourazzak FE, Talbi S, Aradoini N, Berrada K, Keita S \& Hazry T 2015 25-Hydroxy vitamin D and its relationship with clinical and laboratory parameters in patients with rheumatoid arthritis. Clinical Rheumatology 34 353-357. (doi:10.1007/s10067-014-2713-0)

Adorini L \& Penna G 2008 Control of autoimmune diseases by the vitamin D endocrine system. Nature Clinical Practice Rheumatology 4 404-412. (doi:10.1038/ncprheum0855)

Al-Jarallah K, Shehab D, Abraham M, Mojiminiyi OA \& Abdella NA 2013 Musculoskeletal pain: should physicians test for vitamin D level? International Journal of Rheumatic Disease 16 193-197. (doi:10.1111/1756-185X.12066)

Andersen ML \& Tufik S 2003 Sleep patterns over 21-day period in rats with chronic constriction of sciatic nerve. Brain Research 984 84-92. (doi:10.1016/S0006-8993(03)03095-6)

Andersen ML \& Tufik S 2012 Vitamin D as an underlying factor in sleeprelated issues. Journal of Clinical Sleep Medicine 8 699. (doi:10.5664/ jcsm.2268)

Andersen ML, Nascimento DC, Machado RB, Roizenblatt S, Moldofsky $\mathrm{H} \&$ Tufik S 2006 Sleep disturbance induced by substance P in mice. Behavioural Brain Research 167 212-218. (doi:10.1016/j. bbr.2005.09.008)

Araujo P, Hachul H, Santos-Silva R, Bittencourt LR, Tufik S \& Andersen ML 2011 Sleep pattern in women with menstrual pain. Sleep Medicine 12 1028-1030. (doi:10.1016/j.sleep.2011.06.011)

Arnold LM, Sarzi-Puttini P, Arsenault P, Khan T, Brown PB, Clair A, Scavone JM, Driscoll J, Landen J \& Pauer L 2015 Efficacy and safety of pregabalin in patients with fibromyalgia and comorbid depression taking concurrent antidepressant medication: a randomized, placebocontrolled study. Journal of Rheumatology 42 1237-1244. (doi:10.3899/ jrheum.141196)

Bergman P, Sperneder S, Höijer J, Bergqvist J \& Björkhem-Bergman L 2015 Low vitamin D levels are associated with higher opioid dose in palliative cancer patients - results from an observational study in Sweden. PLoS ONE 10 e0128223. (doi:10.1371/journal.pone.0128223)

Bertisch SM, Sillau S, de Boer IH, Szklo M \& Redline S 2015 25-Hydroxyvitamin D concentration and sleep duration and continuity: multi-ethnic study of atherosclerosis. Sleep 38 1305-1311. (doi:10.5665/sleep.4914)

Bhatty SA, Shaikh NA, Irfan M, Kashif SM, Vaswani AS, Sumbhai A \& Gunpat 2010 Vitamin D deficiency in fibromyalgia. Journal of Pakistan Medical Association 60 949-951.

Blanco-Centurion CA \& Salin-Pascual RJ 2001 Extracellular serotonin levels in the medullary reticular formation during normal sleep and after REM sleep deprivation. Brain Research 923 128-136. (doi:10.1016/S0006-8993(01)03209-7)

Bonvanie IJ, Oldehinkel AJ, Rosmalen JG \& Janssens KA 2016 Sleep problems and pain: a longitudinal cohort study in emerging adults. Pain 157 957-963. (doi:10.1097/j.pain.0000000000000466)

Bozkurt NC, Cakal E, Sahin M, Ozkaya EC, Firat H \& Delibasi T 2012 The relation of serum 25-hydroxyvitamin-D levels with severity of obstructive sleep apnea and glucose metabolism abnormalities. Endocrine 41 518-525. (doi:10.1007/s12020-012-9595-1)

Cajochen C, Kräuchi K \& Wirz-Justice A 2003 Role of melatonin in the regulation of human circadian rhythms and sleep. Journal of Neuroendocrinology 15 432-437. (doi:10.1046/j.13652826.2003.00989.x)

Çakır T, Doğan G, Subaşı V, Filiz MB, Ülker N, Doğan ŞK \& Toraman NF 2015 An evaluation of sleep quality and the prevalence of restless leg syndrome in vitamin D deficiency. Acta Neurologica Belgica 115 623-627. (doi:10.1007/s13760-015-0474-4)

Carlander B, Puech-Cathala AM, Jaussent I, Scholz S, Bayard S, Cochen V \& Dauvilliers Y 2011 Low vitamin D in narcolepsy with cataplexy. PLOS ONE 6 e20433. (doi:10.1371/journal.pone.0020433)

Carskadon MA \& Dement WC 2017 Normal human sleep: an overview. In Principles and Practice of Sleep Medicine, edn 6, pp 15-24. Eds $\mathrm{MH}$ Kryger, T Roth \& WC Dement. Philadelphia, PA, USA: Elsevier.

Castro LS, Poyares D, Leger D, Bittencourt L \& Tufik S 2013 Objective prevalence of insomnia in the São Paulo, Brazil Epidemiologic Sleep Study. Annals of Neurology 74 537-546. (doi:10.1002/ana.23945)

Correia A, Azevedo Mdo S, Gondim F \& Bandeira F 2014 Ethnic aspects of vitamin D deficiency. Arquivos Brasileiros de Endocrinologia e Metabologia 58 540-544. (doi:10.1590/0004-2730000003320)

Cui X, Pelekanos M, Liu PY, Burne TH, McGrath JJ \& Eyles DW 2013 The vitamin D receptor in dopamine neurons; its presence in human substantia nigra and its ontogenesis in rat midbrain. Neuroscience 236 77-87. (doi:10.1016/j.neuroscience.2013.01.035)

Cui X, Pertile R, Liu P \& Eyles DW 2015 Vitamin D regulates tyrosine hydroxylase expression: $\mathrm{N}$-cadherin a possible mediator. Neuroscience 304 90-100. (doi:10.1016/j.neuroscience.2015.07.048)

Dauvilliers Y, Evangelista E, Lopez R, Barateau L, Scholz S, Crastes de Paulet B, Carlander B \& Jaussent I 2017 Vitamin D deficiency in type 1 narcolepsy: a reappraisal. Sleep Medicine 29 1-6. (doi:10.1016/j. sleep.2016.05.008)

Davies KA, Macfarlane GJ, Nicholl BI, Dickens C, Morriss R, Ray D \& McBeth J 2008 Restorative sleep predicts the resolution of chronic widespread pain: results from the EPIFUND study. Rheumatology $\mathbf{4 7}$ 1809-1813. (doi:10.1093/rheumatology/ken389)

Davis CJ, Zielinski MR, Dunbrasky D, Taishi P, Dinarello CA \& Krueger JM 2017 Interleukin 37 expression in mice alters sleep responses to inflammatory agents and influenza virus infection. Neurobiology of Sleep and Circadian Rhythms 3 1-9. (doi:10.1016/j.nbscr.2016.11.005)

Deluca HF \& Cantorna MT 2001 Vitamin D: its role and uses in immunology. FASEB Journal 15 2579-2585. (doi:10.1096/fj.010433rev)

de Oliveira DL, Hirotsu C, Tufik S \& Andersen ML 2015 Vitamin D and sleep apnea: beyond a simple association. Journal of Clinical Sleep Medicine 11 1345. (doi:10.5664/jcsm.5206)

Dhesi JK, Bearne LM, Moniz C, Hurley MV, Jackson SH, Swift CG \& Allain TJ 2002 Neuromuscular and psychomotor function in elderly subjects who fall and the relationship with vitamin D status. Journal of Bone and Mineral Research 17 891-897. (doi:10.1359/jbmr.2002.17.5.891)

Drager LF, Togeiro SM, Polotsky VY \& Lorenzi-Filho G 2013 Obstructive sleep apnea: a cardiometabolic risk in obesity and the metabolic syndrome. Journal of the American College of Cardiology 62 569-576. (doi:10.1016/j.jacc.2013.05.045)

Durmer JS \& Dinges DF 2005 Neurocognitive consequences of sleep deprivation. Seminars in Neurology 25 117-129. (doi:10.1055/s-2005-867080)

EFSA NDA Panel (EFSA Panel on Dietetic Products, Nutrition and Allergies) 2016 Scientific opinion on dietary reference values for vitamin D. EFSA Journal 14 4547. (doi:10.2903/j.efsa.2016.4547)

España RA \& Scammell TE 2011 Sleep neurobiology from a clinical perspective. Sleep 34 845-858. (doi:10.5665/SLEEP.1112)

Evatt ML 2015 Vitamin D associations and sleep physiology-promising rays of information. Sleep 38 171-172. (doi:10.5665/sleep.4386)

Eyles DW, Smith S, Kinobe R, Hewison M \& McGrath JJ 2005 Distribution of the vitamin D receptor and 1 alpha-hydroxylase in human brain. Journal of Chemical Neuroanatomy 29 21-30. (doi:10.1016/j. jchemneu.2004.08.006)

Eyles DW, Liu PY, Josh P \& Cui X 2014 Intracellular distribution of the vitamin $\mathrm{D}$ receptor in the brain: comparison with classic target tissues and redistribution with development. Neuroscience 268 1-9. (doi:10.1016/j.neuroscience.2014.02.042) http://joe.endocrinology-journals.org

DOI: $10.1530 / \mathrm{JOE}-16-0514$
() 2017 Society for Endocrinology Printed in Great Britain 
Finan PH, Goodin BR \& Smith MT 2013 The association of sleep and pain: an update and a path forward. Journal of Pain 14 1539-1552. (doi:10.1016/j.jpain.2013.08.007)

Finan PH, Buenaver LF, Coryell VT \& Smith MT 2014 Cognitivebehavioral therapy for comorbid insomnia and chronic pain. Sleep Medicine Clinics 9 261-274. (doi:10.1016/j.jsmc.2014.02.007)

Franklin KA \& Lindberg E 2015 Obstructive sleep apnea is a common disorder in the population-a review on the epidemiology of sleep apnea. Journal of Thoracic Disease 8 1311-1322. (doi:10.3978/j. issn.2072-1439.2015.06.11)

Garcia VA, Hirotsu C, Matos G, Alvarenga T, Pires GN, Kapczinski F, Schröder N, Tufik S \& Andersen ML 2013 Modafinil ameliorates cognitive deficits induced by maternal separation and sleep deprivation. Behavioural Brain Research 253 274-279. (doi:10.1016/j. bbr.2013.07.029)

Garcion E, Wion-Barbot N, Montero-Menei CN, Berger F \& Wion D 2002 New clues about vitamin D functions in the nervous system. Trends in Endocrinology and Metabolism 13 100-105. (doi:10.1016/S10432760(01)00547-1)

Gendelman O, Itzhaki D, Makarov S, Bennun M \& Amital H 2015 A randomized double-blind placebo-controlled study adding high dose vitamin D to analgesic regimens in patients with musculoskeletal pain. Lupus 24 483-489. (doi:10.1177/0961203314558676)

Ghai B, Bansal D, Kanukula R, Gudala K, Sachdeva N, Dhatt SS \& Kumar V 2017 Vitamin D supplementation in patients with chronic low back pain: an open label, single arm clinical trial. Pain Physician 20 E99-E105.

Gopinath K \& Danda D 2011 Supplementation of 1,25 dihydroxy vitamin D3 in patients with treatment naive early rheumatoid arthritis: a randomised controlled trial. International Journal of Rheumatic Disease 14 332-339. (doi:10.1111/j.1756-185X.2011.01684.x)

Gordon NP, Caan BJ \& Asgari MM 2012 Variation in vitamin D supplementation among adults in a multi-race/ethnic health plan population 2008. Nutrition Journal 11 104. (doi:10.1186/1475-289111-104)

Goswami U, Ensrud KE, Paudel ML, Redline S, Schernhammer ES, Shikany JM, Stone KL, Kunisaki KM \& Osteoporotic Fractures in Men Study Research Group 2016 Vitamin D concentrations and obstructive sleep apnea in a multicenter cohort of older males. Annals of the American Thoracic Society 13 712-718. (doi 10.1513/ AnnalsATS.201507-440OC)

Hagenau T, Vest R, Gissel TN, Poulsen CS, Erlandsen M, Mosekilde L \& Vestergaard P 2009 Global vitamin D levels in relation to age, gender, skin pigmentation and latitude: an ecologic meta-regression analysis. Osteoporosis International 20 133-140. (doi:10.1007/s00198-0080626-y)

Hansen AL, Dahl L, Olson G, Thornton D, Graff IE, Frøyland L, Thayer JF \& Pallesen S 2014 Fish consumption, sleep, daily functioning, and heart rate variability. Journal of Clinical Sleep Medicine 10 567-575. (doi:10.5664/jcsm.3714)

Heidari B, Shirvani JS, Firouzjahi A, Heidari P \& Hajian-Tilaki KO 2010 Association between nonspecific skeletal pain and vitamin D deficiency. International Journal of Rheumatic Disease 13 340-346. (doi:10.1111/j.1756-185X.2010.01561.x)

Hicks GE, Shardell M, Miller RR, Bandinelli S, Guralnik J, Cherubini A, Lauretani F \& Ferrucci L 2008 Associations between vitamin D status and pain in older adults: the Invecchiare in Chianti study. Journal of the American Geriatric Society 56 785-791. (doi:10.1111/j.15325415.2008.01644.x)

Higgins MJ, Mackie SL, Thalayasingam N, Bingham SJ, Hamilton J \& Kelly CA 2013 The effect of vitamin D levels on the assessment of disease activity in rheumatoid arthritis. Clinical Rheumatology $\mathbf{3 2}$ 863-867. (doi:10.1007/s10067-013-2174-x)

Hirotsu C, Rydlewski M, Araújo MS, Tufik S \& Andersen ML 2012 Sleep loss and cytokines levels in an experimental model of psoriasis. PLoS ONE 7 e51183. (doi:10.1371/journal.pone.0051183)
Holick MF 2003 Vitamin D deficiency: what a pain it is. Mayo Clinic proceedings 78 1457-1459. (doi:10.4065/78.12.1457)

Holick MF \& Chen TC 2008 Vitamin D deficiency: a worldwide problem with health consequences. American Journal of Clinical Nutrition $\mathbf{8 7}$ 1080S-1086S.

Holick MF, Binkley NC, Bischoff-Ferrari HA, Gordon CM, Hanley DA, Heaney RP, Murad MH, Weaver CM \& Endocrine Society 2011 Evaluation, treatment, and prevention of vitamin D deficiency: an Endocrine Society clinical practice guideline. Journal of Clinical Endocrinology and Metabolism 96 1911-1930. (doi:10.1210/jc.20110385)

Huang W, Shah S, Long Q, Crankshaw AK \& Tangpricha V 2013 Improvement of pain, sleep, and quality of life in chronic pain patients with vitamin D supplementation. Clinical Journal of Pain 29 341-347. (doi:10.1097/AJP.0b013e318255655d)

IOM (Institute of Medicine) 2011 Dietary Reference Intakes for Calcium and Vitamin D. Washington, DC, USA: The National Academies Press. (doi:10.17226/13050)

Jiang P, Xue Y, Li HD, Liu YP, Cai HL, Tang MM \& Zhang LH $2014 a$ Dysregulation of vitamin D metabolism in the brain and myocardium of rats following prolonged exposure to dexamethasone. Psychopharmacology 231 3445-3451. (doi:10.1007/ s00213-014-3440-6)

Jiang P, Zhang LH, Cai HL, Li HD, Liu YP, Tang MM, Dang RL, Zhu WY, Xue Y \& He X $2014 b$ Neurochemical effects of chronic administration of calcitriol in rats. Nutrients 6 6048-6059. (doi:10.3390/nu6126048)

Jones BE 2011 Neurobiology of waking and sleeping. Handbook of Clinical Neurology 98 131-149. (doi:10.1016/B978-0-444-52006-7.00009-5)

Johnson KG, Ziemba AM \& Garb JL 2012 Improvement in headaches with continuous positive airway pressure for obstructive sleep apnea: a retrospective analysis. Headache 53 333-343 (doi:10.1111/j.15264610.2012.02251.x)

Jouvet M 1967 Neurophysiology of the states of sleep. Physiological Reviews 47 117-177.

Kawabata A 2011 Prostaglandin E2 and pain - an update. Biological and Pharmaceutical Bulletin 34 1170-1173. (doi:10.1248/bpb.34.1170)

Kamen DL \& Tangpricha V 2010 Vitamin D and molecular actions on the immune system: modulation of innate and autoimmunity. Journal of Molecular Medicine 88 441-450. (doi:10.1007/s00109-010-0590-9)

Kerley CP, Hutchinson K, Bolger K, McGowan A, Faul J \& Cormican L 2016 Serum vitamin D is significantly inversely associated with disease severity in Caucasian adults with obstructive sleep apnea syndrome: a case control study. Sleep 39 293-300. (doi:10.5665/ sleep.5430)

Kerley CP, Hutchinson K, Bramham J, McGowan A, Faul J \& Cormican L 2017 Vitamin D improves selected metabolic parameters but not neuropsychological or quality of life indices in OSA: a pilot study. Journal of Clinical Sleep Medicine 13 19-26. (doi:10.5664/jcsm.6378)

Kheirandish-Gozal L, Peris E \& Gozal D 2014 Vitamin D levels and obstructive sleep apnoea in children. Sleep Medicine 15 459-463. (doi:10.1016/j.sleep.2013.12.009)

Klaumann PR, Wouk AFPF \& Sillas T 2008 Pathophysiology of pain. Archives of Veterinary Science 13 1-12. (http://dx.doi.org/10.5380/avs. v13i1.11532)

Knutsen KV, Madar AA, Brekke M, Meyer HE, Natvig B, Mdala I \& Lagerløv P 2014 Effect of vitamin D on musculoskeletal pain and headache: a randomized, double-blind, placebo-controlled trial among adult ethnic minorities in Norway. Pain 155 2591-2598. (doi:10.1016/j.pain.2014.09.024)

Kristiansen HA, Kværner KJ, Akre H, Øverland B, Sandvik L \& Russel MB 2011 Sleep apnoea headache in the general population. Cephalalgia 32 451-458. (doi:10.1177/0333102411431900)

Lachmann R, Bevan MA, Kim S, Patel N, Hawrylowicz C, Vyakarnam A \& Peters BS 2015 A comparative phase 1 clinical trial to identify anti-infective mechanisms of vitamin D in people with HIV infection. AIDS 29 1127-1135. (doi:10.1097/QAD.0000000000000666) 
Le Goaziou MF, Kellou N, Flori M, Perdrix C, Dupraz C, Bodier E \& Souweine G 2014 Vitamin D supplementation for diffuse musculoskeletal pain: results of a before-and-after study. European Journal of General Practice 20 3-9. (doi:10.3109/13814788. 2013.825769)

Liguori C, Romigi A, Izzi F, Mercuri NB, Cordella A, Tarquini E, Giambrone MP, Marciani MG \& Placidi F 2015 Continuous positive airway pressure treatment increases serum vitamin D levels in male patients with obstructive sleep apnea. Journal of Clinical Sleep Medicine 11 603-607. (doi:10.5664/jcsm.4766)

Liguori C, Izzi F, Mercuri NB, Romigi A, Cordella A, Tarantino U \& Placidi F 2016 Vitamin D status of male OSAS patients improved after long-term CPAP treatment mainly in obese subjects. Sleep Medicine S1389-S9457 30224-30226. (doi:10.1016/j.sleep.2016,08,022)

Manson JE, Brannon PM, Rosen CJ \& Taylor CL 2016 Vitamin D deficiency - is there really a pandemic? New England Journal of Medicine 375 1817-1820. (doi:10.1056/NEJMp1608005)

Marchand F, Perretti M \& McMahon SB 2005 Role of the immune system in chronic pain. Nature Reviews Neuroscience 6 521-532. (doi:10.1038/ nrn1700)

Mason C, de Dieu Tapsoba J, Duggan C, Wang CY, Korde L \& McTiernan A 2016 Repletion of vitamin D associated with deterioration of sleep quality among postmenopausal women. Preventive Medicine 93 166-170. (doi:10.1016/j.ypmed.2016.09.035)

Massa J, Stone KL, Wei EK, Harrison SL, Barrett-Connor E, Lane NE, Paudel M, Redline S, Ancoli-Israel S, Orwoll E, et al. 2015 Vitamin D and actigraphic sleep outcomes in older community-dwelling men: the MrOS sleep study. Sleep 38 251-257. (doi:10.5665/sleep.4408)

McArthur AJ, Gillette MU \& Prosser RA 1991 Melatonin directly resets the rat suprachiasmatic circadian clock in vitro. Brain Research 565 158-161. (doi:10.1016/0006-8993(91)91748-P)

McBeth J \& Jones K 2007 Epidemiology of chronic musculoskeletal pain. Best Practice and Research Clinical Rheumatology 21 403-425. (doi:10.1016/j.berh.2007.03.003)

McCarty DE, Reddy A, Keigley Q, Kim PY \& Marino AA 2012 Vitamin D, race, and excessive daytime sleepiness. Journal of Clinical Sleep Medicine 8 693-697. (doi:10.5664/jcsm.2266)

McCarty DE, Reddy A, Keigley Q, Kim PY, Cohen S \& Marino AA 2013 Nonspecific pain is a marker for hypovitaminosis D in patients undergoing evaluation for sleep disorders: a pilot study. Nature and Science of Sleep 5 37-42. (doi:10.2147/NSS.S42641)

McCarty DE, Chesson AL Jr, Jain SK \& Marino AA 2014 The link between vitamin D metabolism and sleep medicine. Sleep Medicine Reviews 18 311-319. (doi:10.1016/j.smrv.2013.07.001)

Medicine AAoS 2014 International Classification of Sleep Disorders. Darien, IL, USA: American Academy of Sleep Medicine.

Meier-Ewert HK, Ridker PM, Rifai N, Regan MM, Price NJ, Dinges DF \& Mullington JM 2004 Effect of sleep loss on C-reactive protein, an inflammatory marker of cardiovascular risk. Journal of the American College of Cardiology 43 678-683. (doi:10.1016/j.jacc.2003.07.050)

Meller ST \& Gebhart GF 1993 Nitric oxide (NO) and nociceptive processing in the spinal cord. Pain 52 127-136. (doi:10.1016/03043959(93)90124-8)

Mete T, Yalcin Y, Berker D, Ciftci B, Guven SF, Topaloglu O, Yavuz HC \& Guler S 2013 Obstructive sleep apnea syndrome and its association with vitamin D deficiency. Journal of Endocrinological Investigation 36 681-685. (doi:10.3275/8923)

Millan MJ 2002 Descending control of pain. Progress in Neurobiology 66 355-474. (doi:10.1016/S0301-0082(02)00009-6)

Moreno J, Krishnan AV, Peehl DM \& Feldman D 2006 Mechanisms of vitamin D-mediated growth inhibition in prostate cancer cells: inhibition of the prostaglandina pathway. Anticancer Research $\mathbf{2 6}$ $2525-2530$

Nascimento DC, Andersen ML, Hipólide DC, Nobrega JN \& Tufik S 2007 Pain hypersensitivity induced by paradoxical sleep deprivation is not due to altered binding to brain mu-opioid receptors. Behavioural Brain Research 178 216-220. (doi:10.1016/j.bbr.2006.12.016)

Need AG, Morris HA, Horowitz M \& Nordin C 1993 Effects of skin thickness, age, body fat, and sunlight on serum 25-hydroxyvitamin D. American Journal of Clinical Nutrition 58 882-885.

Orme RP, Bhangal MS \& Fricker RA 2013 Calcitriol imparts neuroprotection in vitro to midbrain dopaminergic neurons by upregulating GDNF expression. PLoS ONE 8 e62040. (doi:10.1371/ journal.pone.0062040)

Osunkwo I, Hodgman EI, Cherry K, Dampier C, Eckman J, Ziegler TR, Ofori-Acquah S \& Tangpricha V 2011 Vitamin D deficiency and chronic pain in sickle cell disease. British Journal of Haematology 153 538-540. (doi:10.1111/j.1365-2141.2010.08458.x)

Ozgurhan G, Vehapoglu A, Vermezoglu O, Temiz RN, Guney A \& Hacihamdioglu B 2016 Risk assessment of obstructive sleep apnea syndrome in pediatric patients with vitamin D deficiency: a questionnaire-based study. Medicine 95 e4632. (doi:10.1097/ MD.0000000000004632)

1994 Part III: pain terms, a current list with definitions and notes on usage. In Classification of Chronic Pain, edn 2, pp 210. Eds H Merskey $\&$ N Bogduk. Seattle, WA, USA: International Association for the Study of Pain Press.

Pérez-Fernandez R, Alonso M, Segura C, Muñoz I, García-Caballero T \& Diguez C 1997 Vitamin D receptor gene expression in human pituitary gland. Life Sciences 60 35-42. (doi:10.1016/S00243205(96)00586-3)

Plotnikoff GA \& Quigley JM 2003 Prevalence of severe hypovitaminosis $\mathrm{D}$ in patients with persistent, nonspecific musculoskeletal pain. Mayo Clinic Proceedings 78 1463-1470. (doi:10.4065/78.12.1463)

Prüfer K, Veenstra TD, Jirikowski GF \& Kumar R 1999 Distribution of 1,25-dihydroxyvitamin D3 receptor immunoreactivity in the rat brain and spinal cord. Journal of Chemical Neuroanatomy 16 135-145. (doi:10.1016/S0891-0618(99)00002-2)

Ren K \& Dubner R 2010 Interactions between the immune and nervous systems in pain. Nature Medicine 16 1267-1276. (doi:10.1038/ nm.2234)

Roehrs T, Hyde M, Blaisdell B, Greenwald M \& Roth T 2006 Sleep loss and REM sleep loss are hyperalgesic. Sleep 29 145-151. (doi:10.1093/ sleep/29.2.145)

Roizenblatt S, Souza AL, Palombini L, Godoy LM, Tufik S \& Bittencourt LR 2015 Musculoskeletal pain as a marker of health quality. Findings from the epidemiological sleep study among the adult population of São Paulo city. PLoS ONE 10 e0142726. (doi:10.1371/journal. pone.0142726)

Rorie A, Goldner WS, Lyden E \& Poole JA 2014 Beneficial role for supplemental vitamin D3 treatment in chronic urticaria: a randomized study. Annals of Allergy, Asthma and Immunology 112 376-382. (doi:10.1016/j.anai.2014.01.010)

Ruiz FS, Andersen ML, Martins RC, Zager A, Lopes JD \& Tufik S 2012 Immune alterations after selective rapid eye movement or total sleep deprivation in healthy male volunteers. Innate Immunity 18 44-54. (doi:10.1177/1753425910385962)

SACN (Scientific Advisory Committee on Nutrition) 2016 Vitamin D and Health. England, UK: Public Health England.

Santos RS, Coelho FM, Silva BC, Graciolli FG, Dominguez WV, Menezes Montenegro FL, Jorgetti V, Moysés RM \& Elias RM 2016 Parathyroidectomy improves restless leg syndrome in patients on hemodialysis. PLOS ONE 11 e0155835. (doi:10.1371/journal. pone.0155835)

Saper CB, Scammell TE \& Lu J 2005 Hypothalamic regulation of sleep and circadian rhythms. Nature 437 1257-1263. (doi:10.1038/nature04284)

Schaible HG \& Richter F 2004 Pathophysiology of pain. Langenbecks Archives of Surgery 389 237-243. (doi:10.1007/s00423-004-0468-9)

Schreuder F, Bernsen RM \& van der Wouden JC 2012 Vitamin D supplementation for nonspecific musculoskeletal pain in http://joe.endocrinology-journals.org

DOI: $10.1530 / J O E-16-0514$
() 2017 Society for Endocrinology Printed in Great Britain 
non-Western immigrants: a randomized controlled trial. Annals of Family Medicine 10 547-555. (doi:10.1370/afm.1402)

Schrimpf M, Liegl G, Boeckle M, Leitner A, Geisler P \& Pieh C 2015 The effect of sleep deprivation on pain perception in healthy subjects: a meta-analysis. Sleep Medicine 16 1313-1320. (doi:10.1016/j. sleep.2015.07.022)

Shipton EE \& Shipton EA 2015 Vitamin D deficiency and pain: clinical evidence of low levels of vitamin D and supplementation in chronic pain states. Pain and Therapy 4 67-87. (doi:10.1007/s40122-0150036-8)

Sivertsen B, Lallukka T, Petrie KJ, Steingrímsdóttir OA, Stubhaug A \& Nielsen CS 2015 Sleep and pain sensitivity in adults. Pain 156 1433-1439. (doi:10.1097/j.pain.0000000000000131)

Skaaby T, Husemoen LL, Thuesen BH \& Linneberg A 2015 Prospective population-based study of the association between vitamin D status and incidence of autoimune disease. Endocrine 50 231-238. (doi:10.1007/s12020-015-0547-4)

Smith AK, Togeiro SM, Tufik S \& Roizenblatt S 2009 Disturbed sleep and musculoskeletal pain in the bed partner of patients with obstructive sleep apnea. Sleep Medicine 10 904-912. (doi:10.1016/j. sleep.2008.08.013)

Stumpf WE \& O'Brien LP 1987 1,25 (OH)2 vitamin D3 sites of action in the brain. An autoradiographic study. Histochemistry 87 393-406. (doi:10.1007/BF00496810)

Thomas M, Sing H, Belenky G, Holcomb H, Mayberg H, Dannals R, Wagner H, Thorne D, Popp K, Rowland L, et al. 2000 Neural basis of alertness and cognitive performance impairments during sleepiness. I. Effects of $24 \mathrm{~h}$ of sleep deprivation on waking human regional brain activity. Journal of Sleep Research 9 335-352. (doi:10.1046/j.13652869.2000.00225.x)

Tufik S, Andersen ML, Bittencourt LRA \& de Mello MT 2009 Paradoxical sleep deprivation: neurochemical, hormonal and behavioral alterations. Evidence from 30 years of research. Anais da Acadêmia Brasileira de Ciências 81 521-538. (doi:10.1590/S000137652009000300016)
Tufik S, Santos-Silva R, Taddei JA \& Bittencourt LR 2010 Obstructive sleep apnea syndrome in the Sao Paulo Epidemiologic Sleep Study. Sleep Medicine 11 441-446. (doi:10.1016/j.sleep.2009.10.005)

Valtueña J, González-Gross M, Huybrechts I, Breidenassel C, Ferrari M, Mouratidou T, Gottrand F, Dallongeville J, Azzini E, Sioen I, et al. 2013 Factors associated with vitamin D deficiency in European adolescents: the HELENA study. Journal of Nutritional Science and Vitaminology 59 161-171. (doi:10.3177/jnsv.59.161)

Van Cauter E, Spiegel K, Tasali E \& Leproult R 2008 Metabolic consequences of sleep and sleep loss. Sleep Medicine 9 S23-S28. (doi:10.1016/S1389-9457(08)70013-3)

Wali S, Shukr A, Boudal A, Alsaiari A \& Krayem A 2015 The effect of vitamin D supplements on the severity of restless legs syndrome. Sleep and Breathing 19 579-583. (doi:10.1007/s11325-014-1049-y)

Walker MP \& Stickgold R 2004 Sleep-dependent learning and memory consolidation. Neuron 44 121-133. (doi:10.1016/j.neuron.2004.08.031)

Wepner F, Scheuer R, Schuetz-Wieser B, Machacek P, Pieler-Bruha E, Cross HS, Hahne J \& Friedrich M 2014 Effects of vitamin D on patients with fibromyalgia syndrome: a randomized placebo-controlled trial. Pain 155 261-268. (doi:10.1016/j.pain.2013.10.002)

Wu Z, Malihi Z, Stewart AW, Lawes CMM \& Scragg R 2016 Effect of vitamin $\mathrm{D}$ supplementation on pain: a systematic review and metaanalysis. Pain Physician 19 415-427.

Yang J, Liu L, Zhang Q, Li M \& Wang J 2015 Effect of vitamin D on the recurrence rate of rheumatoid arthritis. Experimental and Therapeutic Medicine 10 1812-1816. (doi:10.3892/etm.2015.2747)

Yilmaz R, Salli A, Cingoz HT, Kucuksen S \& Ugurlu H 2016 Efficacy of vitamin D replacement therapy on patients with chronic nonspecific widespread musculoskeletal pain with vitamin D deficiency. International Journal of Rheumatic Disease 19 1255-1262. (doi:10.1111/1756-185X.12960)

Zager A, Andersen ML, Ruiz FS, Antunes IB \& Tufik S 2007 Effects of acute and chronic sleep loss on immune modulation of rats. American Journal of Physiology Regulatory, Integrative and Comparative Physiology 293 R504-R509. (doi:10.1152/ajpregu.00105.2007)

Received in final form 3 April 2017

Accepted 21 April 2017
๑) 2017 Society for Endocrinology Printed in Great Britain 